\title{
Effect of Insulin With Oral Nutrients on Whole-Body Protein Metabolism in Growing Pubertal Children With Type 1 Diabetes
}

\author{
IEVA BRAZIUNIENE, JEREMY GARLICK, IZOLDA MILEVA, VARDHINI DESIKAN, THOMAS A. WILSON, \\ AND MARGARET MCNURLAN
}

Departments of Pediatrics [I.B., J.G., V.D., T.A.W.] and Surgery [J.G., I.M., M.M.], Stony Brook University Medical Center, Stony Brook, New York 11794

\begin{abstract}
Insulin treatment of children with insulin-dependent diabetes mellitus improves whole body protein balance. Our recent study, conducted in pubertal children with type 1 diabetes with provision of both insulin and amino acids, indicated a positive effect of insulin on protein balance, primarily through decreased protein degradation. The current study was undertaken to assess the effect of insulin on protein metabolism in adolescents with type 1 diabetes during oral provision of a complete diet. Whole-body protein metabolism in six pubertal children (13-17 y) with type 1 diabetes mellitus was assessed with $\mathrm{L}-\left[1-{ }^{13} \mathrm{C}\right]$ leucine during a basal (insulinwithdrawn) period and during infusion of $0.15 \mathrm{U} / \mathrm{kg} / \mathrm{h}$ regular insulin with hourly meals to meet protein and energy requirements. Net leucine balance was significantly higher with insulin and nutrients $(13.1 \pm 6.3 \mu \mathrm{mol}$ leucine $/ \mathrm{kg} / \mathrm{h})$ than in the basal state $(-21.4 \pm 2.8$, $p<0.01)$ with protein degradation decreased from $138 \pm 5.6 \mu \mathrm{mol}$ leucine $/ \mathrm{kg} / \mathrm{h}$ to $108 \pm 5.9(p<0.01)$ and no significant change in protein synthesis. Even with an ample supply of nutrients, insulin does not increase whole-body protein synthesis in pubertal children with type 1 diabetes mellitus and positive protein balance is solely due to a substantial reduction in the rate at which protein is degraded.
\end{abstract}

(Pediatr Res 65: 109-112, 2009)

$\mathrm{P}$ rotein metabolism in a human body is a continuous process involving both the degradation of body protein and continual protein synthesis. Lean body mass can be gained or lost because of changes in either of these processes or simultaneous changes in both. Although provision of insulin clearly reverses the negative nitrogen balance associated with diabetes and increases lean body mass (1), the mechanism by which insulin exerts an anabolic effect is still somewhat unclear.

In young, growing animals insulin stimulates protein synthesis in muscle tissue even in the absence of provision of nutrients (2-4) although this ability of insulin to stimulate protein synthesis declines with age $(5,6)$. Similarly, provision of insulin to adults with type 1 failed to stimulate protein synthesis in muscle tissue $(7,8)$ and in the whole body $(7,9,10)$, but rather the anabolic effect was due to a reduction in the rate of protein degradation.

Studies in prepubertal (11) and pubertal children (12) with type 1 diabetes also failed to demonstrate an increase in

Received April 17, 2008; accepted July 29, 2008

Correspondence: Margaret McNurlan, Ph.D., Department of Surgery, Stony Brook University Medical Center, Stony Brook, NY 11794-8191; e-mail: Margaret. mcnurlan@stonybrook.edu

Supported by grants from the National Institute of Health M01RR00109 to the University of Vermont and M01RR01710 to Stony Brook University Medical Center. whole-body protein synthesis with provision of insulin. However, the interpretation of these results is complicated by the ability of insulin to induce changes in the plasma levels of amino acids. In normal subjects providing amino acids along with insulin increased the rate of whole-body protein synthesis $(13,14)$. Two studies in subjects with type 1 diabetes have also reported enhanced whole-body protein synthesis with provision of both insulin and amino acids $(15,16)$ although a further study suggested that the insulin and amino acids suppressed the rate of protein degradation in muscle tissue without impacting on the rate of protein synthesis (17). Because studies with amino acids and insulin reported somewhat contradictory findings, the current study was undertaken to examine the effect of insulin on whole-body protein metabolism in growing adolescents with type 1 diabetes who were provided with a more realistic provision of nutrients as oral meals containing sufficient protein, carbohydrate, and fat to meet energy needs.

\section{METHODS AND SUBJECTS}

Six pubertal adolescents (Table 1) enrolled in the study approved by the institutional review board and conducted at the General Clinical Research Center of Stony Brook University Medical Center. All subjects gave written assent and their parents provided written parental permission after the purpose, nature, and potential risks of the study were explained.

Protocol. The study was conducted on two consecutive days (study day 1 and 2) each of which lasted $7 \mathrm{~h}$. Subjects were admitted to the General Clinical Research Center in the evening preceding study day 1. Insulin was withdrawn from the subjects with the following schedule. For those on subcutaneous insulin injections, the last dose of the long-acting insulin was administered $36 \mathrm{~h}$ before the beginning of study day 1 ; for those on intermediate-acting insulin, the last dose was given $24 \mathrm{~h}$ before beginning study day 1 ; and for those on short-acting insulin, the last dose was given $8 \mathrm{~h}$ before the study began. For subjects on subcutaneous insulin injections, short-acting insulin was provided in the interval between study day 1 and 2 and was discontinued $8 \mathrm{~h}$ before beginning study day 2 . For subjects on insulin pumps, the pump was reconnected between study day 1 and 2 and discontinued $4 \mathrm{~h}$ before the beginning of study day 2. Both study days began after an overnight fast.

On study day 1 , subjects were assessed during $3 \mathrm{~h}$ of insulin withdrawal and for $4 \mathrm{~h}$ with the infusion of insulin at a rate of $0.15 \mathrm{U} / \mathrm{kg} / \mathrm{h}$ after an initial bolus of $0.15 \mathrm{U} / \mathrm{kg}$. During the $4 \mathrm{~h}$ of insulin infusion, subjects also consumed hourly meals. The liquid meals consisted of $3 \%$ of energy as fat, $63 \%$ of energy as carbohydrate, and 33\% of energy as protein (Carnation Instant Breakfast made with skim milk) and were given so that each meal contained $1 / 12$ of the subject's caloric requirement, calculated as 1.4 times the estimated basal energy expenditure (18).

On study day $2, \mathrm{~L}-\left[1-{ }^{13} \mathrm{C}\right]$ leucine was infused as a primed infusion to assess whole-body protein kinetics as previously described $(12,19)$. A priming amount of $6 \mu \mathrm{mole} / \mathrm{kg} \mathrm{L}-\left[1-{ }^{13} \mathrm{C}\right]$ leucine (Cambridge Isotopes, Andover, MA)

Abbreviations: KIC, $\alpha$-ketoisocaproate; MPE, moles percent excess 
Table 1. Characteristics of the subjects

\begin{tabular}{lcc}
\hline & Mean \pm SEM & Range \\
\hline Gender 3M:3F & & \\
Age (y) & $15 \pm 1$ & $12.8-17.1$ \\
Duration of diabetes $(\mathrm{y})$ & $9 \pm 2.5$ & $0.7-15.9$ \\
Height $(\mathrm{cm})$ & $168 \pm 1$ & $164.2-172.6$ \\
Weight $(\mathrm{kg})$ & $58.4 \pm 1.8$ & $52.8-64.5$ \\
Height velocity $(\mathrm{cm} / \mathrm{y})$ & $4.59 \pm 1.4$ & $1.7-10.6$ \\
Weight velocity $(\mathrm{kg} / \mathrm{y})$ & $3.77 \pm 1.54$ & $1.74-9.18$ \\
Tanner stage & $3.8 \pm 0.2$ & $3.0-4.0$ \\
Insulin dose $(\mathrm{U} / \mathrm{kg} / \mathrm{d})$ & $0.85 \pm 0.04$ & $0.72-0.97$ \\
Hemoglobin A1C $(\%)$ & $8.9 \pm 0.6$ & $7.4-11.1$ \\
\hline
\end{tabular}

was administered, followed by a continuous infusion $(6 \mu \mathrm{mol} / \mathrm{kg} / \mathrm{h})$. As with study day 1 , study day 2 consisted of $180 \mathrm{~min}(3 \mathrm{~h})$ of basal period without feeding and $240 \mathrm{~min}(4 \mathrm{~h})$ when insulin was infused continuously along with $\mathrm{L}-\left[1-{ }^{13} \mathrm{C}\right]$ leucine and hourly, oral meals were consumed.

The glucose concentration in arterialized blood samples (20) was monitored every 15 min during the $4 \mathrm{~h}$ of insulin infusion with a Beckman glucose analyzer (Beckman instruments, Fullerton, CA). In addition, blood samples were also collected before the start of tracer infusion and every 15 min during the last hour of each segment of the study (basal and during insulin infusion with oral nutrients) for the determination of the enrichment of ${ }^{13} \mathrm{C}$ leucine and $\alpha$-ketoisocaproate (KIC), for the concentration of insulin and for the concentration of amino acids in plasma. Samples of expired air were collected at the same time as the blood samples. Expired air was collected into evacuated glass vacutainer tubes for the determination of ${ }^{13} \mathrm{CO}_{2}$ isotopic enrichment. The rate of $\mathrm{CO}_{2}$ production was determined by respiratory gas exchange using a ventilated hood (Delta Track Respiratory Gas Monitor, Yorba Linda, CA) during the last hour of the basal and insulin with oral nutrient periods. The enrichment of expired ${ }^{13} \mathrm{CO}_{2}$ due to diet alone was determined on study day 1 and used to correct ${ }^{13} \mathrm{CO}_{2}$ production from L- $\left[1-{ }^{13} \mathrm{C}\right]$ leucine on study day 2 .

Plasma glucose and insulin. The concentration of plasma glucose was measured with a Beckman II Glucose Analyzer based on glucose oxidase. Plasma insulin concentrations were determined by radioimmunoassay (Diagnostic Products Corp., Los Angeles, CA).

Plasma amino acids. The concentration of amino acids in plasma were determined by high pressure liquid chromatography with a Waters system with fluorescence detection of the ortho-phthalaldehyde/3-mercaptopropionic acid derivative.

Protein kinetics. Measurement of the enrichment of L- $\left[1-{ }^{13} \mathrm{C}\right]$ leucine and KIC from the plasma was as described previously $(12,19,21)$. Briefly the enrichment of L- $\left[1-{ }^{13} \mathrm{C}\right]$ leucine was measured with a VG MD 800 quadrupole gas chromatography mass spectrometry (Fisons MD 800, San Jose, CA) after conversion to the tertiary butyldimethylsilyl- and quinoxalinol tertiary butyldimethylsilyl-derivatives, respectively. The abundance of ${ }^{13} \mathrm{CO}_{2}$ in breath was measured by gas isotope ratio-mass spectrometry at the General Clinical Research Center at the University of Vermont with a VG SIRA II Isotope Ratio Mass Spectrometer (Middlewich, Cheshire, UK) as described previously (22).

Calculations. All kinetic data were calculated at near steady state conditions of $\left[{ }^{13} \mathrm{C}\right]$ leucine and $\left[{ }^{13} \mathrm{C}\right] \mathrm{KIC}$ isotopic enrichment in the plasma and ${ }^{13} \mathrm{CO}_{2}$ isotopic enrichment in expired air achieved during the last hour of the basal and insulin plus nutrient periods. Plasma $\alpha$-KIC was taken to represent the enrichment of leucine at the site of oxidation, i.e. intracellular $\left[{ }^{13} \mathrm{C}\right]$ leucine (23). Data were analyzed with a stochastic model described by Golden and Waterlow (24), where leucine flux (Q) is calculated from the rate (i) and enrichment of infusate (Ei) and the enrichment of plasma KIC (Ep):

$\mathrm{Q}(\mu \mathrm{mole} / \mathrm{kg} / \mathrm{h})=\mathrm{i} \mathrm{Ei} / \mathrm{Ep}$

The contribution of infused leucine to total flux was subtracted from Q to obtain endogenous flux.

The rate of leucine oxidation was calculated by dividing the rate of expired ${ }^{13} \mathrm{CO}_{2}$ production by plasma KIC enrichment with a correction of 0.8 for recovered $\mathrm{CO}_{2}$ (19). The rate of nonoxidative leucine disposal (NOLD or protein synthesis) and the rate of appearance of leucine from protein degradation were calculated from flux $(\mathrm{Q})$ with the following equation:

$\mathrm{Q}=\mathrm{NOLD}+$ oxidation = protein degradation + leucine intake and net leucine balance, an index of net protein accretion or anabolism, was calculated as protein degradation-protein synthesis.

Statistics. Two tailed paired t test was used to compare data in the basal and infusion periods. Data are expressed as mean \pm SEM. $p<0.05$ was considered significant.

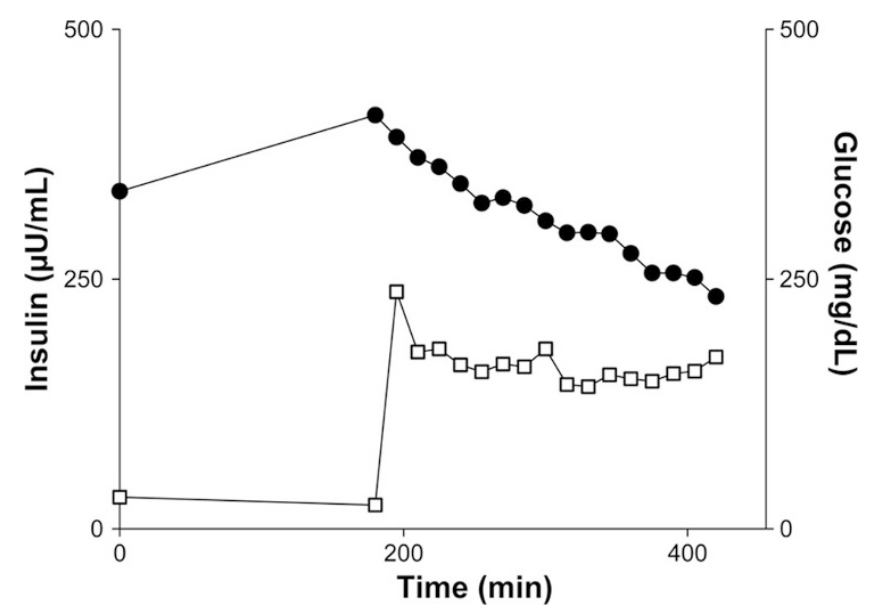

Figure 1. Change in serum glucose and insulin concentrations. Plasma concentrations of glucose $(\mathrm{mg} / \mathrm{dL})(\bullet)$ and insulin $(\mu \mathrm{U} / \mathrm{mL})(\square)$ in six pubertal children with type 1 diabetes. The time from 0 to $180 \mathrm{~min}$ represents the basal period during which time subjects were withdrawn from insulin treatment. From 180 to $420 \mathrm{~min}$, subjects received an intravenous infusion of $0.15 \mathrm{U}$ regular insulin $/ \mathrm{kg} / \mathrm{h}$ along with oral ingestion of nutrients. Plasma glucose and insulin were determined as described in Materials and Methods.

\section{RESULTS}

Three male and three female subjects with a mean age of $15 \mathrm{y}$ and a duration of type 1 diabetes of $9 \mathrm{y}$ participated in the study (Table 1). The subjects were growing, with a height velocity of $4.6 \mathrm{~cm}$ per year. During the period of insulin withdrawal, the plasma glucose levels were $338 \pm 38.6$ $\mathrm{mg} / \mathrm{dL}$, whereas the plasma insulin levels were $28.3 \pm 9.8$ $\mu \mathrm{U} / \mathrm{mL}$ (Fig. 1). With the infusion of insulin and oral intake of nutrients, the concentration of glucose in the plasma declined significantly $(p<0.001)$ to $254 \pm 14.1 \mathrm{mg} / \mathrm{dL}$ and insulin rose significantly $(p=0.05)$ to $156.6 \pm 19.9 \mu \mathrm{U} / \mathrm{mL}$. The concentrations of amino acids in the plasma are shown in Table 2. There were significant changes in the concentration of alanine, serine, glycine, tryptophan, isoleucine, leucine, and lysine between the basal period and the period of insulin and oral nutrients.

The enrichment of plasma leucine was $5.22 \pm 0.066$ moles percent excess (MPE) in the insulin-withdrawn state and declined to $4.56 \pm 0.119$ with the infusion of insulin and the provision of oral nutrients. The enrichment of plasma KIC was significantly $(p<0.001)$ lower than that of leucine both in the basal state, $4.20 \pm 0.096 \mathrm{MPE}$ and during provision of the insulin and nutrients, $3.42 \pm 0.100$ MPE. Plasma KIC enrichment was taken to represent the enrichment of leucine within tissues and was therefore used to calculate protein kinetics. With plasma KIC enrichment the calculated rate of wholebody protein synthesis was $117 \pm 6.4 \mu \mathrm{mol}$ leucine/kg body weight/h during insulin withdrawal and did not change significantly with the provision of insulin and oral nutrients, $121 \pm$ $6.4 \mu \mathrm{mol}$ leucine/kg body weight/h (Fig. 2). Protein degradation was significantly higher during insulin withdrawal, $138 \pm$ $5.6 \mu \mathrm{mol}$ leucine $/ \mathrm{kg}$ body weight $/ \mathrm{h}$ than during the provision of insulin and oral nutrients, $108 \pm 5.9 \mu \mathrm{mol}$ leucine $/ \mathrm{kg}$ body weight/h $(p<0.01)$. Protein oxidation was significantly lower $(p<0.01)$ in the insulin withdrawal period $(21.4 \pm 2.8)$ than during the provision of insulin and oral nutrients $(62.7 \pm 7.3)$. 
Table 2. Concentration of amino acids in plasma during the basal period and during provision of insulin and oral nutrients

\begin{tabular}{lcc}
\hline & $\begin{array}{c}\text { Basal period } \\
(\mu \text { moles/L })\end{array}$ & $\begin{array}{c}\text { Insulin }+ \text { nutrients } \\
(\mu \text { moles/L) }\end{array}$ \\
\hline Alanine & $187 \pm 14$ & $267 \pm 14^{*}$ \\
Glutamic acid & $45 \pm 2.8$ & $47 \pm 2.6$ \\
Asparagine & $54 \pm 6.3$ & $58 \pm 4.8$ \\
Serine & $85 \pm 4.8$ & $71 \pm 2.4^{*}$ \\
Glutamine & $408 \pm 37$ & $371 \pm 21$ \\
Histidine & $96 \pm 14$ & $106 \pm 9.7$ \\
Glycine & $126 \pm 4.9$ & $109 \pm 3.7^{*}$ \\
Threonine & $89 \pm 6.5$ & $80 \pm 4.3$ \\
Arginine & $57 \pm 5.5$ & $54 \pm 4.1$ \\
Aspartic acid & $20 \pm 0.9$ & $19 \pm 0.7$ \\
Phenylalanine & $73 \pm 4.9$ & $79 \pm 3.0$ \\
Tyrosine & $70 \pm 5.1$ & $64 \pm 2.5$ \\
Valine & $333 \pm 17$ & $317 \pm 12$ \\
Methionine & $26 \pm 2.0$ & $20 \pm 2.1$ \\
Tryptophan & $99 \pm 8.2$ & $134 \pm 7.0^{*}$ \\
Isoleucine & $140 \pm 7.6$ & $111 \pm 4.9^{*}$ \\
Leucine & $280 \pm 16$ & $217 \pm 10^{*}$ \\
Lysine & $107 \pm 8.7$ & $147 \pm 11 \dagger$ \\
\hline
\end{tabular}

Amino acid concentrations in plasma were determined by HPLC as described in Methods. The differences between the basal period and during provision of insulin and oral nutrients are significant at $* p<0.01$ and $\dagger p<0.05$

Whole-body protein balance was negative in the absence of insulin $(-21.4 \pm 2.8)$ and increased significantly with the provision of insulin and oral nutrients $(13.1 \pm 6.3, p<0.01)$ (Fig. 2).

If the enrichment of plasma leucine is used instead of the enrichment of plasma KIC to calculate protein kinetics, the magnitude of the change in leucine balance is the same. With plasma leucine enrichment, the change in balance was not due to changes in the rate of protein degradation alone, but was the result of a decrease in both protein synthesis and degradation.

\section{DISCUSSION}

This study demonstrates an anabolic effect of insulin with the provision of oral nutrients in adolescents with type 1 diabetes due to a reduction in the rate at which whole-body protein is degraded. An earlier study had demonstrated reduced protein degradation when insulin was given along with intravenous amino acids compared with a state of insulin withdrawal (12) consistent with studies in adults with type 1 diabetes $(8,9,16,17)$ and prepubertal children with type 1 diabetes (11).

In the study of Godil et al. (12), provision of insulin and amino acids improved protein balance, but overall balance was still negative indicating an overall loss of body protein. In the present study, oral nutrients including carbohydrate and fat were provided and at a higher level of caloric intake than in the earlier study and in this study, protein balance improved from -21 to $+13 \mu \mathrm{mol}$ leucine $/ \mathrm{kg}$ body weight $/ \mathrm{h}$. It is not possible to distinguish an effect of increased caloric intake from an effect due to increased provision of amino acids because the present study had both increased energy and increased amino acids (leucine intake increased from 31 to 76 $\mu \mathrm{mol}$ leucine/kg body weight/h). However, the present study

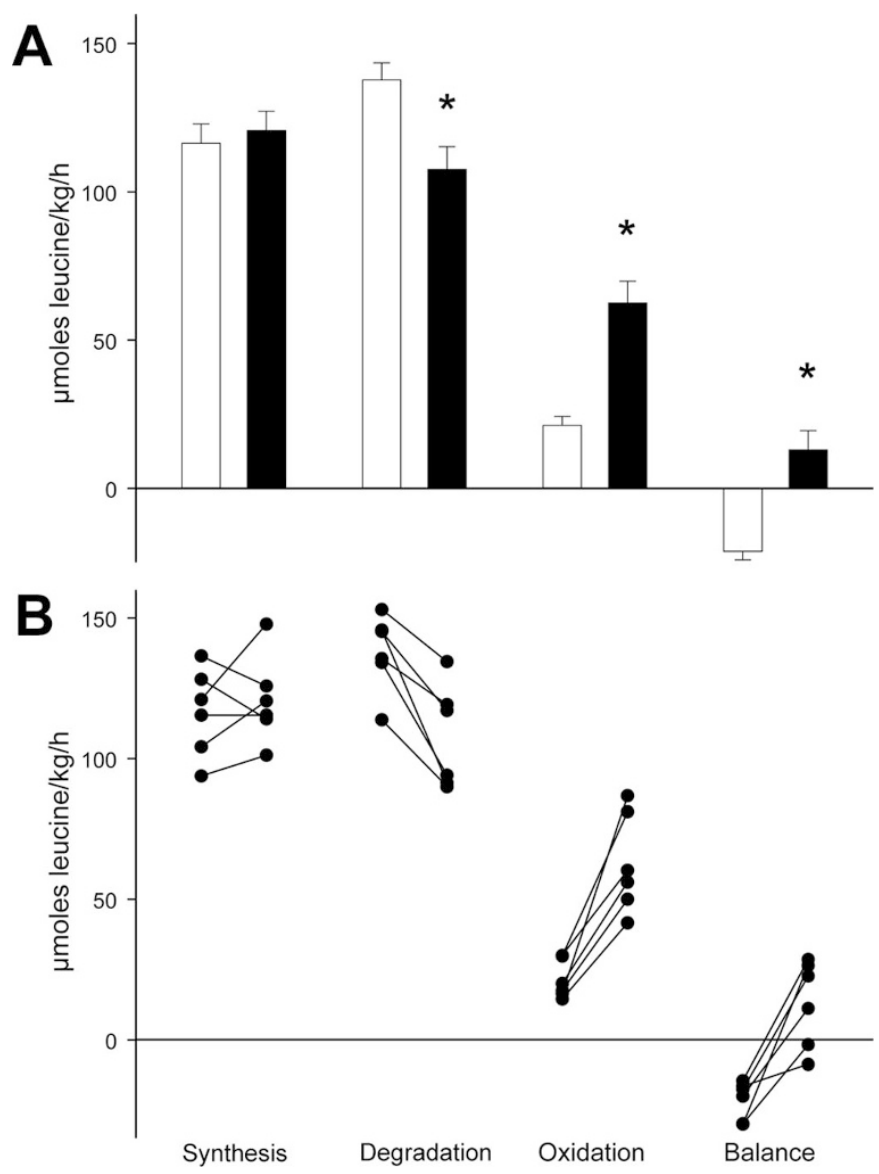

Figure 2. Leucine kinetics in type 1 diabetic adolescents during insulin withdrawal and insulin replacement with oral nutrients. $A$, The mean values + SE during insulin withdrawal $(\square)$ and insulin replacement with oral nutrients (ם). $B$, Values during insulin withdrawal (left) and insulin replacement with oral nutrients (right) for each individual subject. Protein synthesis (nonoxidative leucine disposal), protein degradation, leucine oxidation, and leucine balance were calculated from the enrichment of plasma $\left[{ }^{13} \mathrm{C}\right] \mathrm{KIC},{ }^{13} \mathrm{CO}_{2}$, and $\mathrm{CO}_{2}$ production as described in Materials and Methods. The data are expressed as $\mu$ moles of leucine $/ \mathrm{kg}$ body weight $/ \mathrm{h}$ during a basal, insulin withdrawn period $(0-180 \mathrm{~min})$ and during the provision of $15 \mathrm{U}$ insulin and oral nutrients (180-429 min). Differences between the basal period and during the infusion of insulin + oral nutrients were statistically significant, $* p<0.01$.

does confirm that even with the provision of adequate nutrients, the main anabolic effect of insulin is the reduction in the rate of whole-body protein degradation rather than an increase in the rate of protein synthesis.

If whole-body protein synthesis was already maximally stimulated by the amount of insulin circulating in the basal state, it might not be possible for a further increase in insulin to affect protein synthesis. In this study, the measured basal concentrations of insulin were $28.3 \pm 9.8 \mu \mathrm{U} / \mathrm{mL}$. However, in this study, as in that of Godil et al. (12), insulin concentrations were measured with an insulin-antibody radioimmunoassay. This assay overestimates insulin concentrations if insulin antibodies are present in the serum samples. Although the changes in insulin concentration between the basal and fed periods represent real changes, it is possible that the measured basal levels are inappropriately high. Another limitation of the present study is that measurement of whole-body protein 
metabolism could mask changes in individual tissues, e.g. muscle tissue or changes in individual proteins. Although it is technically possible to measure the rate of muscle protein synthesis and to isolate particular proteins for study, the techniques involve multiple biopsies and, therefore, are not appropriate in children.

The inability of insulin to stimulate protein synthesis observed in the present study is consistent with a number of studies of whole-body $(9,16)$ and muscle protein metabolism $(8,17)$ in adults and studies of whole-body protein metabolism in prepubertal children with type 1 diabetes $(11,12)$. The results of the present study contrast with other studies of both whole-body (13-16) and muscle protein metabolism (25-27) and animal studies suggesting that insulin-stimulated protein synthesis in muscle by enhancing the initiation of mRNA translation (reviewed in 28). It is possible that insulin has a greater effect on protein synthesis in muscle tissue as suggested by the results from animal studies (28) and that this effect is masked in measurements of whole-body protein metabolism by other types of tissues in which protein synthesis is not affected. The studies of muscle tissue in adults $(8,17)$ tend to suggest that is not the entire explanation for the differing conclusions among studies. A more likely explanation has been provided by Fujita et al. (29) who have suggested that the differences among studies may be reconciled by whether or not amino acids were provided in addition to insulin. In their study, rates of protein synthesis in muscle tissue were increased when insulin increased blood flow and amino acid delivery. It is possible that in the present study oral feeding did not increase amino acid concentrations sufficiently to facilitate the stimulation of protein synthesis.

In conclusion, our study suggests that the primary anabolic effect of insulin on protein metabolism in adolescents with type 1 diabetes mellitus at the level of the whole-body is inhibition of whole-body proteolysis. No evidence of the ability of insulin to stimulate protein synthesis was apparent in these adolescent subjects, even when they received plentiful amounts of amino acids and energy through adequate feeding.

Acknowledgments. We thank the subjects and their families for participating in this research. We also thank the nursing staff of the General Clinical Research Center and Ms. Dawn Sasvary from the Core Lab for all their help in the completion of this work.

\section{REFERENCES}

1. Walsh CH, Soler NG, James H, Harvey TC, Thomas BJ, Fremlin JH, Fitzgerald MG, Malins JM 1976 Studies in whole body potassium and whole body nitrogen in newly diagnosed diabetics. Q J Med 45:295-301

2. Baillie AG, Garlick PJ 1991 Responses of protein synthesis in different skeletal muscles to fasting and insulin in rats. Am J Physiol 260:E891-E896

3. Garlick PJ, Fern M, Preedy VR 1983 The effect of insulin infusion and food intake on muscle protein synthesis in postabsorptive rats. Biochem J 210:669-676

4. Jefferson LS, Li JB, Rannels SR 1977 Regulation by insulin of amino acid release and protein turnover in the perfused rat hemicorpus. J Biol Chem 252:1476-1483
5. Baillie AG, Garlick PJ 1992 Attenuated responses of muscle protein synthesis to fasting and insulin in adult female rats. Am J Physiol 262:E1-E5

6. Wray-Cahen D, Nguyen HV, Burrin DG, Beckett PR, Fiorotto ML, Reeds PJ, Wester TJ, Davis TA 1998 Response of skeletal muscle protein synthesis to insulin in suckling pigs decreases with development. Am J Physiol 275:E602-E609

7. Pacy PJ, Bannister PA, Halliday D 1991 Influence of insulin on leucine kinetics in the whole body and across the forearm in post-absorptive insulin dependent diabetic (type 1) patients. Diabetes Res 18:155-162

8. Pacy PJ, Nair KS, Ford C, Halliday D 1989 Failure of insulin infusion to stimulate fractional muscle protein synthesis in type I diabetic patients. Anabolic effect of insulin and decreased proteolysis. Diabetes 38:618-624

9. Nair KS, Ford GC, Halliday D 1987 Effect of intravenous insulin treatment on in vivo whole body leucine kinetics and oxygen consumption in insulin-deprived type I diabetic patients. Metabolism 36:491-495

10. Robert JJ, Beaufrere B, Koziet J, Desjeux JF, Bier DM, Young VR, Lestradet H 1985 Whole body de novo amino acid synthesis in type I (insulin-dependent) diabetes studied with stable isotope-labeled leucine, alanine, and glycine. Diabetes 34:67-73

11. Vogiatzi MG, Nair KS, Beckett PR, Copeland KC 1997 Insulin does not stimulate protein synthesis acutely in prepubertal children with insulin-dependent diabetes mellitus. J Clin Endocrinol Metab 82:4083-4087

12. Godil MA, Wilson TA, Garlick PJ, McNurlan MA 2005 Effect of insulin with concurrent amino acid infusion on protein metabolism in rapidly growing pubertal children with type 1 diabetes. Pediatr Res 58:229-234

13. Castellino P, Luzi L, Simonson DC, Haymond M, DeFronzo RA 1987 Effect of insulin and plasma amino acid concentrations on leucine metabolism in man. Role of substrate availability on estimates of whole body protein synthesis. J Clin Invest 80:1784-1793

14. Tessari P, Inchiostro S, Biolo G, Trevisan R, Fantin G, Marescotti MC, Iori E, Tiengo A, Crepaldi G 1987 Differential effects of hyperinsulinemia and hyperaminoacidemia on leucine-carbon metabolism in vivo. Evidence for distinct mechanisms in regulation of net amino acid deposition. J Clin Invest 79:1062-1069

15. Inchiostro S, Biolo G, Bruttomesso D, Fongher C, Sabadin L, Carlini M, Duner E, Tiengo A, Tessari P 1992 Effects of insulin and amino acid infusion on leucine and phenylalanine kinetics in type 1 diabetes. Am J Physiol 262:E203-E210

16. Luzi L, Castellino P, Simonson DC, Petrides AS, DeFronzo RA 1990 Leucine metabolism in IDDM. Role of insulin and substrate availability. Diabetes 39:38-48

17. Bennet WM, Connacher AA, Jung RT, Stehle P, Rennie MJ 1991 Effects of insulin and amino acids on leg protein turnover in IDDM patients. Diabetes 40:499-508

18. Food and Nutrition Board IOM 2005 Dietary Reference Intakes. Washington, DC: The National Academies Press, p 1331

19. Melville S, McNurlan MA, McHardy KC, Broom J, Milne E, Calder AG, Garlick PJ 1989 The role of degradation in the acute control of protein balance in adult man: failure of feeding to stimulate protein synthesis as assessed by L-[1-13C]leucin infusion. Metabolism 38:248-255

20. Abumrad NN, Rabin D, Diamond MP, Lacy WW 1981 Use of a heated superficial hand vein as an alternative site for the measurement of amino acid concentrations and for the study of glucose and alanine kinetics in man. Metabolism 30:936-940

21. Garlick PJ, McNurlan MA, McHardy KC, Calder AG, Milne E, Fearns LM, Broom J 1987 Rates of nutrient utilization in man measured by combined respiratory gas analysis and stable isotopic labelling: effect of food intake. Hum Nutr Clin Nutr 41:177-191

22. Toth MJ, MacCoss MJ, Poehlman ET, Matthews DE 2001 Recovery of (13)CO(2) from infused [1-(13)C]leucine and [1,2-(13)C(2)]leucine in healthy humans. Am J Physiol Endocrinol Metab 281:E233-E241

23. Matthews DE, Schwarz HP, Yang RD, Motil KJ, Young VR, Bier DM 1982 Relationship of plasma leucine and alpha-ketoisocaproate during a L-[1-13C]leucine infusion in man: a method for measuring human intracellular leucine tracer enrichment. Metabolism 31:1105-1112

24. Golden MH, Waterlow JC 1977 Total protein synthesis in elderly people: a comparison of results with [15N]glycine and [14C]leucine. Clin Sci Mol Med 53:277-288

25. Biolo G, Declan Fleming RY, Wolfe RR 1995 Physiologic hyperinsulinemia stimulates protein synthesis and enhances transport of selected amino acids in human skeletal muscle. J Clin Invest 95:811-819

26. Hillier TA, Fryburg DA, Jahn LA, Barrett EJ 1998 Extreme hyperinsulinemia unmasks insulin's effect to stimulate protein synthesis in the human forearm. Am J Physiol 274:E1067-E1074

27. Newman E, Heslin MJ, Wolf RF, Pisters PW, Brennan MF 1994 The effect of systemic hyperinsulinemia with concomitant amino acid infusion on skeletal muscle protein turnover in the human forearm. Metabolism 43:70-78

28. Kimball SR, Farrell PA, Jefferson LS 2002 Invited review: role of insulin in translational control of protein synthesis in skeletal muscle by amino acids or exercise. J Appl Physiol 93:1168-1180

29. Fujita S, Rasmussen BB, Cadenas JG, Grady JJ, Volpi E 2006 Effect of insulin on human skeletal muscle protein synthesis is modulated by insulin-induced changes in muscle blood flow and amino acid availability. Am J Physiol Endocrinol Metab 291:E745-E754 